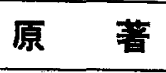

\title{
地域における刷掃指導効果
}

——年後の経過観察— ${ }^{*}$

\section{One Year Observation of Periodontal Health after Toothbrushing Instruction in a Community}

\author{
木 村 年 秀** 岸 本 悦 央** 森 田 学** \\ 石川昭 ${ }^{* *}$ 友實 毅 ${ }^{* *}$ 渡邊達夫** \\ Toshihide KIMURA**, Etsuo KISHIMOTO**, Manabu MORITA**, \\ Akira ISHIKAWA ${ }^{* *}$, Tsuyoshi TOMOZANE ${ }^{* *}$ and Tatsuo WATANABE**
}

Received April 2, 1991 ; accepted May 22, 1991

\begin{abstract}
This study was designed to evaluate the effect of toothbrushing instruction on the periodontal health in a community. The area is $30.5 \mathrm{~km}^{2}$ and has a population of 14,000 .

Ninety-five inhabitants (mean age: 47.6 \pm 9.0 ) participated in this study. Oral examinations were made regarding gingival inflammatory indices, tooth mobility, Oral Hygiene Index, and CPITN scores at baseline, after 1 and 2 months, and 1 year. Each time, the subjects were instructed in the toothpick method of toothbrushing intraorally. They were required to fill out questionnaires to evaluate the oral health behavior and improvement of the subjective symptoms at the final visit.

Significant improvement in the CPITN code was observed during a year. Gingival inflammatory indices improved at 1 and 2 months, but slight relapse of gingival conditions were observed in some subjects. Comparison between the relapsed group and the continuously improving group for a year, revealed that the relapsed group had a significantly lower prevalence of gingival inflammation at baseline.

The questionnaire showed the subjects' great satisfaction with the toothbrushing instruction. About $90 \%$ of them indicated positive improvement of dental health behavior. Forty percent of the participants reported improvement of bleeding gums and $18 \%$ improvement of bad breath.

These results suggested that this dental health education program was effective in the community and that inhabitants affected by periodontal disease were more easily motivated than others.
\end{abstract}

索引用語 : 地域曾科保健, 歯周疾患, 刷掃指導, つま楊子法

Koy words: Public dental service, Periodontal disease, Toothbrushing instruction, Toothpick method

* 本論文の要旨は, 第32回秋季日本歯周病学会で報告した。

**岡山大学歯学部予防歯科学講座（主任：渡蒌達夫教授）

** Department of Preventive Dentistry, Okayama University Dental School (Director: Prof. Tatsuo WATANABE) 


\section{緒 言}

歯周疾患の疫学調查報告は, 過去において数多くなさ れている1-12)。そのいずれに括いてむ成人のほとんどが 歯肉に何らかの所見を有しており， 口腔衛生教育が必要 であると報告している。また，最近の拔歯の原因調查に よれば，40歳以降，歯周疾患による抜歯の割合が急增し ていることが示されている18-16)。职失歯数を減少させ， 生涯自分の歯で食生活を楽しむ状況を実現するために は，歯周疾患の予防を公衆衛生レベルで行うことが必須 である。我々は，歯間部清掃法による刷掃が歯周治療に 効果的であることを臨床的に示した ${ }^{17,18)}$ 。また，公衆衛 生の場に扔いても，集団に対し刷掃指導を行い，その有 効性を報告してきた ${ }^{19,20) 。 ~}$

岡山県灘崎町では，昭和62年 4 月より住民を対象に歯 槽澧漏予防講座を開講し, 検診, 歯科衛生教育及び刷担 指導を行っている。そして, 受講期間中 2 ヶ月で歯肉の 状焦が改善することを示してきた ${ }^{21)}$ 。今回我々は，受講 生に対して約 1 年後, 再診查とアンケートを行い, 指導 効果の持続について検討を加えたので報告する。

\section{対象および方法}

\section{1. 対象}

昭和 62 年 4 月から昭和 63 年 9 月にかけて灘崎町におけ る歯槽膿漏予防講座を受講した者 165 名のうち約 1 年後 に診查扝よびアンケートを受けた 95 名（男性 5 名，女性 90 名，平均年齢 $47.6 \pm 9.0$ 歳）を対象とした。

灘崎町は岡山市に隣接する人口約 1 万 4 千人，面積 30.5 $\mathrm{km}^{2}$ の農業を主産業とする町で，歯科医師数は 4 人であ る。

\section{2. 講座内容}

講座は，月 1 回， 3 ヶ月を 1 コースとし，灘崎町保健 センターにて実施した。1 回目に，スライドを利用した 歯科衛生教育を約 1 時間行い，同時に位相差顕微鏡で受 講者のプラークを見せ，モチベーションの一助とした。 その後, 診查に加え歯科医師が被検者一人ひとりに対し て刷掃指導を行った。刷掃は，歯間部の清掃を主目的と するつま楊子法 ${ }^{17)} に$ 統一し, 術者が実際に受講者の口腔 内を刷掃する口内法 ${ }^{22}$ により指導した。2 回目には，同 一の診查・刷掃指導，3回目には，それらに加え，1回 指導後の結果の報告及び再教育を行った。そして, 約 1 年後に再診查と簡単なアンケートを行った。

\section{3. 診查項目及び診査基準}

診査歯は，動摇度については全歯，それ以外の診查項
目は \begin{tabular}{l|l|l|l}
76 & 6 & 1 & 67 \\
\hline 76 & 1 & 67
\end{tabular} を代表歯とし，上頻は近心㛲側， 下顎は近心舌側を診查した。検診は自然光の下で行い， 人工照明を補助として用いた。該当歯が欠損している場 合, 各ブロック内の残存歯全にてついて診查を行った。 発赤, 腫脹, プロービング後の出血の診査項目について は平岩らの方法222 従い，所見を有するものを 1 , 有し ないものを 0 とした。動摇度は渡燠ら た。清挦度は Debris Index ${ }^{28)}$ で，CPITN による診查 は $\mathrm{Ainamo}^{24)}$ らが示した部分診查法にのっとり実施し た。

尚，各指数は，検者が十分にトレーニングを行い，検 者間での基準の統一を行った。また, 可能な限り同一検 者が同一被検者を診查するようにした。

4. 統計分析

CPITN コード分布の差の検定は, $\chi^{2}$-検定を, また各 炎症症状の有所見部位率の差の検定には paired $t$-test を用いた。

\section{結 果}

1. アンケート回答状況

約 1 年後アンケートを行った結果を, Table 1 亿示し ている。歯磨き回数は 1 日 2 回の人が最も多く約半数を 占めていた。歯磨き時間は平均約 4 分であった。歯磨き 方法については，ほとんど（95\%）が講座で習った歯磨 き方法を続けて抢り，そのうち84\%の人が勧められた歯 ブラシを用いて歯磨きを行っていると回答した。講座の 受講や習った歯磨き方法を他の人に勧めた人は, 非常に 多くそれぞれ $91 \% ， 87 \%$ あった。

受講後改善された自覚症状に関しては「口の中がさっ ぱりする」と回答した者が $83.2 \%$ で最も多く,ついで「ブ ラッシング時の出血が止まった」 $40.0 \%$,「口臭がなくな った」 $17.9 \%$ であった。約半数の人が受講後, 歯科医院 を受診し, う蝕治療, 歯石除去等の処置を受けていた。

2. 診查結果

(1) CPITN の変化

Fig. 1 に CPITN 個人コードの経時的変化を示して ある。初診時では，コード 3 が最も多く76.6\%，ついで コード 4 が16.0\%であり，コード0の者はいなかった。 経時的にみるとコード 3 の割合が減少し(1年後 $53.7 \%)$,

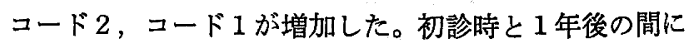
は，有意な分布の差を認めた $\left(p<0.005, \chi^{2}\right.$-検定)。

次に CPITN について各セクスタント別にみた(Table 2)。これによると，臼歯部は前歯部に比べて重度の 者の割合が多かった。経時的には臼歯部で症状の改善が 
Table 1 Results of the questionnaire

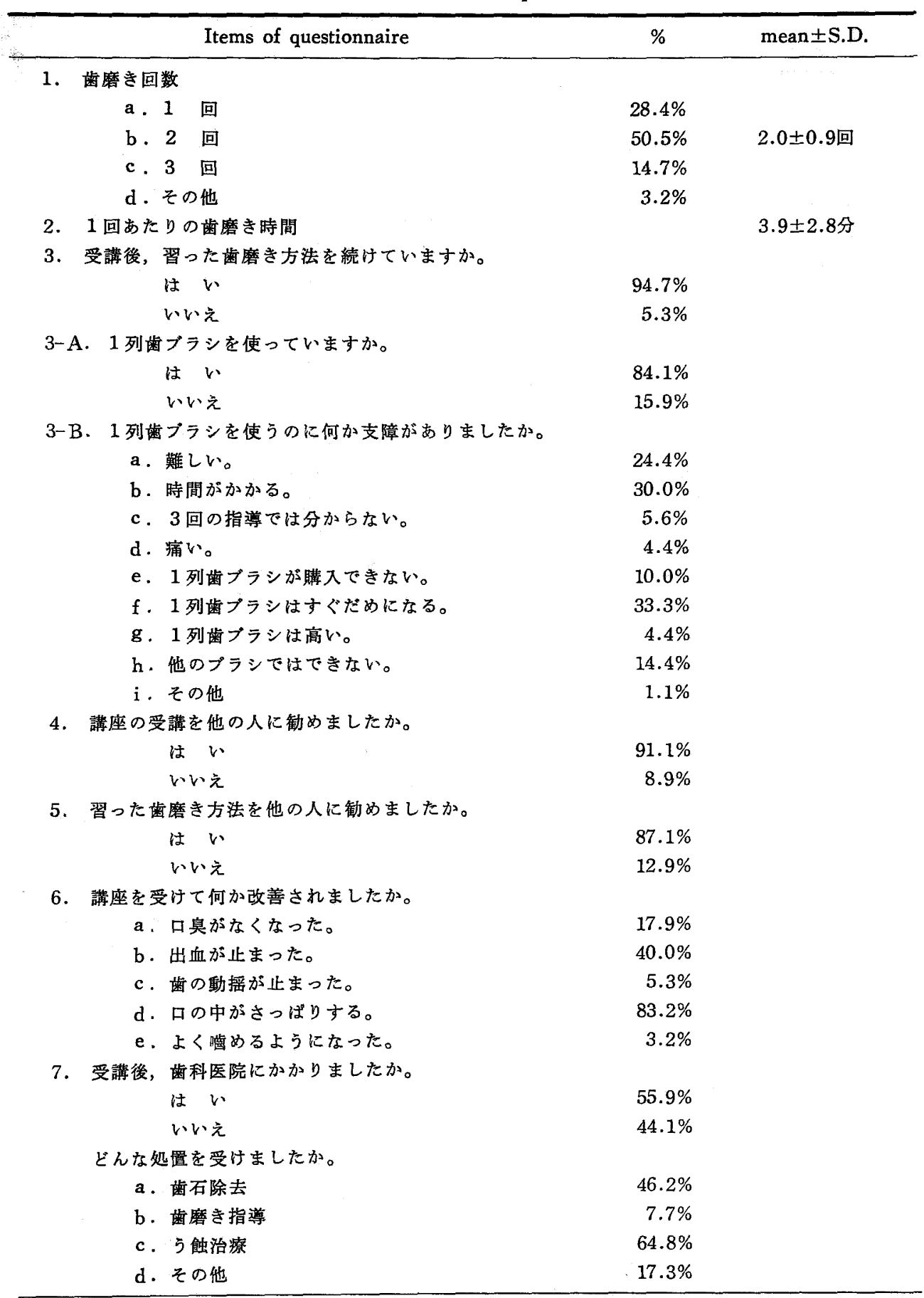




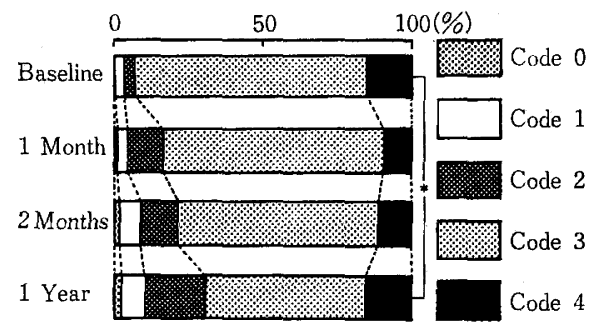

Fig. 1 Percent distribution of CPITN Code $*$ : significant difference by $\chi^{2}$-test, $p<0.005$

認められ，左側上狉臼歯部，右側下顎臼歯部の初診時と 1 年後の閒に有意な差が認められた $(p<0.05)$ 。前歯部 においては有意な改善が認められなかった。

（2）歯肉の状態の変化

発赤, 腫脹, プロービング後の出血の各有所見歯率の 変化を Fig. 2 に示した。いずれの所見も 2 ヶ月目まで 改善しているが， 2 ヶ月目と 1 年後の間で有所見歯率が 增加しており，その傾向は特に腫脹，プロービング後の 出血で著しかった。発赤, 腫脹においては初診時と 1 年 後の間で有意な有所見歯率の 減少が認められた $(p<$ 0.005)。

また，動摇度については， 1 年間で変化が認められな かった。清掃度は, 各歯肉炎指数と同様の傾向が認めら れた。

歯肉炎指数の有所見歯率が講座終了後, 1 年間で増加 していることから，受講者の中に後戻りする者がいるこ
とが考えられた。後戻りする原因を追求する目的で， 2 ヶ月目と比べ， 1 年後に有所見歯率が增加した者の集団 (悪化群)と 1 年後もさらに 持続的に 改善した者の集団 (改善群)の 2 群に分けて,各指数の違いを検討してみた。 いずれの所見においても，改善群は悪化群より 2 ヶ月目 までの有所見歯率が高かった。その傾向は,特に初診時, 2 ヶ月目に著しく統計学的に有意な差を認めた。1 年後 には，悪化群の方が改善群より有所見歯率が高くなって いた（Fig. 2)。両群の間には年齢の有意差は認められ なかったが，改善群の方が男性の割合が有意に高かった。

アンケート回答状況は，いずれの症状においても悪化 群，改善群の閒で有意な差は認られなかった。

\section{考察}

今回の菊槽澧漏予防講座は灘崎町町民を対象に, 地域 歯科保健活動の試みとして行われたものである。ある集 団の歯周疾患䍜患状態，治療必要度を把握する指数とし て CPITN がある。この指数を用いた診查では,コー ド0 (健康) の者はいなく, 全ての受講者に対して口腔 清掃指導が必要であることが示された。コードの分布を

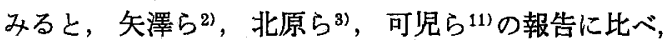
コード 3 の者の割合が高く, 森田 ${ }^{10)} ら$ の報告と類似して いた。

刷掃指導による CPITN コードの改善についての報 告は少ない。本講座の 2 ヶ月間の経過観察においては CPITN コードの有意な改善は認められなかった ${ }^{21)}$ 。今 回, 1 年後の診査において, 初診時との間に有意な改善

Table 2 Percent distribution of CPITN code according to sextants

\begin{tabular}{|c|c|c|c|c|c|c|c|c|c|c|c|c|c|c|c|}
\hline Sextant : Upper & & & Right & & & & & Front & & & & & Left & & \\
\hline Code & 0 & 1 & 2 & 3 & 4 & 0 & 1 & 2 & 3 & 4 & 0 & 1 & 2 & 3 & 4 \\
\hline Baseline & 12.1 & 15.4 & 13.2 & 51.6 & 7.7 & 33.7 & 27.0 & 10.1 & 25.8 & 3.4 & 8.9 & 17.8 & 5.6 & 60.0 & $7.8-$ \\
\hline 1 month & 16.9 & 15.7 & 9.6 & 53.0 & 4.8 & 47.6 & 24.4 & 8.5 & 19.5 & 0 & 19.3 & 10.8 & 8.4 & 59.0 & 2.4 \\
\hline 2 months & 28.0 & 12.0 & 8.0 & 49.3 & 2.7 & 50.7 & 19.2 & 9.6 & 19.2 & 1.4 & 24.0 & 12.0 & 6.7 & 53.3 & 4.0 \\
\hline 1 year & 25.8 & 22.5 & 11.2 & 33.7 & 6.7 & 42.2 & 33.3 & 7.8 & 14.4 & 2.2 & 23.9 & 15.2 & 13.0 & 43.5 & $4.3-$ \\
\hline Sextant : Lower & & & Right & & & & & Front & & & & & Left & & \\
\hline Code & 0 & 1 & 2 & 3 & 4 & 0 & 1 & 2 & 3 & 4 & 0 & 1 & 2 & 3 & 4 \\
\hline Baseline & 14.1 & 15.2 & 14.1 & 46.7 & $9.8-$ & 18.1 & 10.6 & 52.1 & 16.0 & 3.2 & 12.4 & 16.9 & 11.2 & 53.9 & $5.6-$ \\
\hline 1 month & 22.4 & 9.4 & 25.9 & 37.6 & $4.7 \underset{\%}{\mid}$ & 25.6 & 5.8 & 48.8 & 18.6 & 1.2 & 21.7 & 12.0 & 19.3 & 43.4 & $3.6 \%$ \\
\hline 2 months & 24.0 & 13.3 & 20.0 & 40.0 & $2.7 \stackrel{x}{i}$ & 32.5 & 5.2 & 51.9 & 9.1 & 1.3 & 30.6 & 9.7 & 19.4 & 36.1 & $4.2-1$ \\
\hline 1 year & 27.2 & 26.1 & 12.0 & 30.4 & $4.3-$ & 18.9 & 16.8 & 52.6 & 7.4 & 4.2 & 23.0 & 25.3 & 13.8 & 34.5 & 3.4 \\
\hline
\end{tabular}

※ : significant difference by $\chi^{2}$-test, $p<0.05$ 


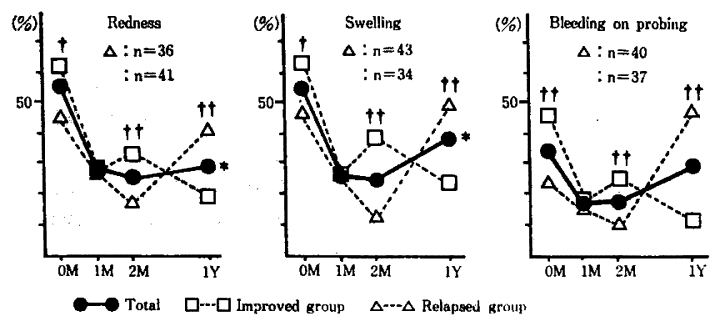

Fig. 2 Change in the prevalence of gingival inflammation

* : significant difference between baseline and 1 year. $p<0.005$

$\dagger$ : significant difference between improved group and relapsed group, $p<0.05$ †† : $p<0.005$

が認められ，講座終了後も指導効果は持続していること が示された。小西ら ${ }^{25)}$ は歯磨き習慣と歯周疾患との関係 を研究し，歯周組織を良好な状態に保持するためには， 歯磨き習慣が重要であることを示した。今回の長期的観 察においても歯磨き指導の重要性が再確認できた。

セクスタント別にみると, 前歯部では改善が認められ なかったが，臼歯部において有意な改善が認められた。 これは，日歯部は前歯部に比べ重篤な部位が多く，より 効果が現れやすかったためと考えられる。また，アンケ 一トの結果，46\%の者が受講期間中に歯科医院で歯石除 去を受けていたことがわかった。このことが，CPITN コードの改善に反映されたのかもしれない。しかし，歯 石除去された部位が臼歯部であるかどうかは，不明であ る。

講座終了時と 1 年後を比較して歯肉炎の有所見歯率に よって悪化群, 改善群に分けてそれぞれの特徴を分析し た。アンケートの回答状況は, 両群間で有意な差は認め られなかった。しかし, 有意差はなかったものの改善群 は悪化群よりも「つま楊子法が難しい」と回答した者が 多く，また，1 日平均歯磨き時間が長い傾向があった。 それぞれの歯周組織の状態を分析すると，改善群の方が 悪化群に比べ, 受講期間中, 特に初診時において, 各炎 症指数の有所見歯率が高かった。すなわち，歯肉の炎症 が持続して改善するグループには, 最初の状態が悪い者 が多く, 講座終了後, 後戻りするグループには, 最初比 較的軽症の者が多かった。この理由として，歯周組織の 状態が悪い者は良い者に比へ, 刷掃指導の際, 症状の改 善を自覚することができ，モチベーションが容易であっ たためと推察できる。今後, 比較的症状が軽い者に対す るモチベーション22)をより徹底する必要性が示された。
アンケートの結果, ほとんどの人が勧められた歯ブラ シ，刷掃方法を継続しており，講座の受講や刷掃方法を 家族や友人に勧めたと回答した。平岩ら ${ }^{199}$ は百货店従業 員33名（平均年龄31.6歳）に対し, 初診時, 2 週後, 3 r月後の 3 回, 今回と同様つま楊子法にて刷掃指導を行 った。その結果, 約 1 年後 $64 \%$ の者が習った歯磨き方法 を実施していると回答した。今回の研究では実施してい る者は, 95\%であり, 百貨店従業員での結果よりさらに 多くの者が継続して習った歯磨き方法を実施していた。 これは今回の対象者の年龄が高く (平均年齡47.6歳), 刷 掃指導のモチベーションが容易であったためと考えられ る。平岩ら ${ }^{19)}$ は, 実施群の方が非実施群よりも平均年齢 が高いと報告しており，実施率の差が年龄によるもので あると推察できる。

今回のアンケート結果より, 受講者は口腔清掃の重要 性を理解し, 受講したことに対し満足感を得ることがで きたと考えられる。実際,「口の中がさっぱりする」,「出 血が止まった」「口臭がなくなった」等, 症状の改善を自 覚している。症状改善の自覚が刷掃習慣の持続, 他の人 にも勧める行動へとモチベートしたと思われる。

現状を考えると, 地域, 職場においてなんらかの具体 的処置を早急に講じなければならない。公衆衛生の場で, 齿周疾患に対する歯科衛生教育, 刷掃指導を行い, その 効果を評価した報告は少ない26,27)。平岩ら ${ }^{19)}$, 鶴見ら ${ }^{20)}$ は職場における歯科衛生教育, 刷掃指導の有効性を示し てきた。地域においても短期閒の効果があることは明ら かであり ${ }^{21)}$, 今回さらに, 1 年後でもその効果が持続し ていることが示された。今回のプログラムは, 公衆衛生 活動で応用できる可能性を示しており，今後，いろいろ な地域集団に対して働きかけていかなければならない。

\section{まとめ}

灘崎町歯槽膿漏予防講座受講者を対象に歯科検診と歯 科保健活動, 刷掃指導を行い, その効果を 1 年間にわた って観察した。その結果,

1. 受講者は症状改善を自覚しており, 講座受講に対 して満足感を得ていた。

2. 1 年間で CPITN 個人コードの有意な改善が認 められ，今回のプログラムの有効性が示された。

3. 発赤, 腫脹, プロービング後の出血の各症状は, 講座期間中 2 ヶ月で改善が認められたが, 約 1 年後に 2 ヶ月目と比べて悪化するものがみられた。

4. 各症状が 1 年後に後戻りするものは, 持続的に改 善する群より受講期間中の有所見歯率が低いという特徽 
があった。

\section{謝辞}

稿を終わるに当たり，本研究に御協力下さいました灘 崎町保健衛生課の皆様に感謝いたします。

\section{文献}

1）矢澤正人，石渡美砂子，荒木 督，田中澄子, 大倉慶子，五十里一秋，酒井美栄子, 経塚直子, 鎌谷研三，中山幸子，栗原久子，熊谷長慶，佐 々木好幸 : CPITN (WHO) を用いた歯周疾 患の疫学的調查一東京都杉並区に括いて一， 口 腔衛生会誌, $34 ; 454-455,1984$.

2）北原稔，高野敬子，堸内欣治，松坂佳代子, 向井晴二: CPITN を用いた歯周疾患䍜患状況 の把握一藤沢市における事例一, 口腔衛生会誌, $34 ; 576-582,1984$.

3）石川 烈，本間昭悟，萩原さっき，浅井 浩, 長田豊, 和泉雄一, 渡辺 久, 泉澤勝害, 野 口俊英 : CPITN (Community Periodontal Index of Treatment Needs) による歯周疾患 の疫学調査（第 1 報）日歯周誌, $26 ; 767-777$, 1984.

4) 鈴木祐平, 神山義信, 米田栄吉, 墹内 博 : Community Periodontal Index of Treatment Needs（CPITN）による歯周疾患調査，日歯 周誌, 27 ; 473-481, 1985.

5）萩原さつき，本間昭悟，浅井浩，今野寿美， 大島光宏, 泉澤勝䩺, 野口俊英, 石川 烈: CPIT N (Community Periodontal Index of Treatment Needs) による歯周疾患の疫学調查 (第 2 報)，日歯周誌，27；635-642，1985.

6）鈴木祐平, 熊谷俊也, 茂木久和, 米田栄吉, 堀 内 博: CPITN (WHO) による女子中・高 生の歯周疾患調查, 日歯周誌， $27 ; 881-889$, 1985.

7）佐々木良紀，高橋義一，石井俊文：海上自衛隊 における歯周疾患管理へのアプローチ その 1 . CPITN による歯周疾患罹患状態の把握, 口腔 衛生会誌, $35 ；$ 498-499， 1985.

8）井村久史, 渡辺充春, 杉田育紀, 吉村博孝, 新 庄文明：某金融機関に括ける産業歯科保健活動 I一歯周疾患を中心とした口腔健診一, 口腔衛 生会誌, $35 ; 508-509,1985$.

9）森田学, 平岩 弘, 小泉和浩, 正村蕒佐雄, 渡邉達夫, 藤原正之：農山村地区における歯周 病の疫学調査一CPITN を用いての検討一，岡 山歯誌, $5 ; 55-61,1986$.

10）可児端夫，飯野新太郎，可児徳子，磯崎篤則， 䔳保琭巳，広㖽晃子, 奥野雅典, 加藤裕久, 伊 川英二, 桑原外喜, 梶田秀行, 奥田 稔: 事業 所從業員の CPITN 調查一CPITN と VPI 括よび自党症状の関連性について一，口腔衛生
会誌, $36 ; 296-305,1986$.

11）坂田真理子, 森田 学, 鶴見真由美, 恵谷潤三, 小泉和浩, 岡崎畺奈美, 岸本悦央, 渡邊達夫 : CPITN を用いた大学新入生の齿科検診, 口腔 衛生会誌, $36 ; 354-355,1986$.

12）厚生省健康政策局歯科衛生課：昭和62年歯科疾 患実態調查報告，口腔保健協会，東京，1989， 115-122頁.

13) Curilovic, Z. : Die Ursachen des Zahnverlustes in der Schweiz. Resultate einer Umfrage bei Privatzahnarzten, Schweiz Monatschr Zahnheilkd, 89 ; 727-737, 1979.

14) Ainamo, J., Sarkki, L., Kuhalampi, M. L., Palolampi, L. and Piirto, O.: The frequency of periodontal extractions in Finland, Community Dent. Health, 1 ; 32-39, 1984.

15) Cahen, P. M., Frank, R. M. and Turlot, C. : A survey of thereasons for dental extractions in France, J. Dent. Res., 64 ; 1087-1093, 1985.

16）木村年秀, 楠本雅子, 小泉和浩, 森田 学, 平 岩 弘, 渡邊達夫, 近常良孝, 坪井甫之: 拔歯 の原因調查: 郵便調查法を用いての検討, 口腔 衛生会誌, 37 ; 570-571， 1987.

17）渡邊達夫, 森田 学, 平岩 弘, 岸本悦央: 歯 口清掃による動摇歯の改善と宿主因子の関係, 口腔衛生会誌, $34 ; 220-225,1984$.

18）森田学, 鶴見真由美, 平岩弘, 坂田真理子, 岩本悦央, 近藤充宏, 渡邊達夫 : 歯口清掃に上 る動摇度の改善一動摇度测定装置 (TMC-01) を用いての検討一， 日歯周誌， $29 ； 205-210$, 1987.

19）平岩 弘, 鶴見真由美, 森田学, 坂田真理子, 岸本悦央, 渡邊達夫 : 百貨店従業員一の刷掃指 導勃果一 1 年間の観察一, 日歯周誌, $28 ; 670-$ 680, 1986.

20）鶴見真由美，森田 学, 平岩 弘,坂田真理子, 恵谷潤三, 岡崎真奈美, 小泉和浩, 正村真佐雄, 今井兼武, 岸本悦央, 渡遥夫 : 曾科検診と同 時に実施した刷授指導効果について，岡山歯誌， $6 ; 81-86,1987$.

21）岸本悦央，石川 昭，友惯 毅，龍野恵美子, 木村年秀, 楠本雅子, 森田 学, 渡燠達夫 : 地 域に扣ける歯槽澧漏予防講座の効果, 岡山歯誌, $8 ; 87-92,1989$.

22) 平岩 弘, 森田 学, 渡邊達夫 : 歯周病患者に おける口内法による刷淿指導と位相差顕微鏡を 用いての患者教育の効果, 日齔周誌，27; 602609, 1985.

23) Greene, J. C. and Vermillion, J. R. : The oral hygiene index. A method for classifying oral hygiene status, J. Amer. Dent. Ass., $61 ; 172-179,1960$.

24) Ainamo, J., Barmes, D., Beagrie, G., Cutress, T., Martin, J. and Sardo-Infirri, J. : 
Development of the World Health Organization Community Periodontal Index of Treatment Needs. Int. Dent. J., 32 ; 281$291,1982$.

25）小西浩二, 楠 責治, 岩本義史, 渡邉達夫, 中 村 亮, 过川次郎, 藤田雄三, 小川洋子, 松村 輝男: 成人集団に拈ける歯科保健活動 第 1 報 菌みがき習慣と CPITN に上る歯周疾患の評 価，口腔衛生会誌，37；677-687， 1987.
26）熊谷典子，市橋 透，松村輝男，長島 暲，千 田 彰, 石井拓男, 啝原悠紀田郎: 名古屋市内 某事務所に招ける歯科保健活動 その $1 . \mathrm{CP}$. ITN の刷授指導への応用, 口腔衛生会誌, 36 ; 358-359, 1986.

27）近藤 誠, 師岡成美, 河合二郎, 岡田直治, 岡 田治夫 : 某事務所における歯科保健管理につ、 て，CPITN に基づいた処置及びその評価，口 腔衛生会誌, 37 ; 434-435, 1987. 